821.163.41.09:398

https://doi.org/10.18485/msc.2018.47.2.ch7

Драгољуб Ж. ПЕРИЋ*

Универзитет у Новом Саду

Филозофски факултет
Оригинални научни рад

Примљен: 14. 11. 2017.

Прихваћен: 27. 12. 2017.

\title{
ПРЕДСТАВА ХРАНЕ И СЛИКЕ ГОЗБЕ У СРПСКИМ УСМЕНИМ КОЛЕДАРСКИМ И БОЖИЋНИМ ПЕСМАМА
}

\begin{abstract}
У овом раду, уз коришћење структурално-семиотичке методологије, посматрани су мотиви хране, односно каталози јела, присутни у 100 српских божићних и коледарских песама, одабраних на основу репрезентативности или архаичности. За разлику од претходних истраживања, првенствено фолклористичког карактера, ${ }^{1}$ рад примарно има поетолошко утемељење, премда ни обредни контекст није занемарен. Основни циљ рада био је да покаже, посредством представа везаних за култну храну (пре свега - божићну печеницу и хлеб), како је у датом корпусу песама рефлектован постепени прелазак са људске жртве на животињску, односно како се у традицији напоредо „памте” старији (териоморфизам) и млађи (антропоморфизам) типови веровања.

Кључне речи: коледарске и божићне песме, култна храна, обред, ритуално преждеравање, сточарски и аграрни култови, народна смеховна култура.
\end{abstract}

У лиминално време смене посне мрсном трпезом - од Варина дне (Св. Мученица Варвара, Варварица, када се кува ритуална храна од житарица (panspermia), до краја поста - Божића, по Вуковим речима, „почиње се пјевати Божићу”: „Поручује Варица Божићу / Да јој пошље од прасца ножицу, / Да зачини варицу шеницу” (Караџић 1988: бр. 193; Караџић 1973: бр. 90; Бован 2000: бр. 11 и др.). Гранично време, на равни обреда, обележено је кувањем варице (јело од различитог зрневља, обавезно пшенице) - хране које припада култу мртвих и коју приносе на дар духовима вегетације зарад плодности усева (в. Беговић: 105-106). Њена припрема - два дана уочи Св. Николе (Св. Варвара, 17.12)르 иреме конзумирања, понекад све до Божића (па и за Божић), указују на неодвојиво преплитање аграрних и сточарских култова у оквиру празновања овог празника. И док у оквиру посне трпезе (поготово на

*dragoljub.peric@ff.uns.ac.rs

${ }^{1}$ B: Карановић, Јокић 2009 и Торњански Брашњовић 2015.

2 Ритуално време припреме „меморисано” је у стиховима песме: „Варица вари / Савица лади, / Николица куса” (Беговић 1986: 105; в. и Врчевић 1883: 15; Караџић 1857: 8 и др.). 
Бадњи дан) доминирају реликти старих аграрних култова, везани за семе и обнову вегетације, уношењем божићне печенице и ритуалним радњама везаним за њу, ове прежитке земљорадничких култова почињу потискивати и надвладавати елементи сточарских култова, притом их не искључујући.

У Врчевићевом опису слављења Божића (1883: 9-68) смењују се и гомилају призори хране и обиље - пре свега - месних производа и прерађевина од меса, као и вина. Храна се лајтмотивски појављује: од покладног (Белог) четвртка, када се коље и припрема божићни мрс (Врчевић 1883: 13), преко посне трпезе, сувог воћа, приганица и слаткиша (на Материце - Врчевић 1883: 15), и Бадњег дана, када домаћица припрема посну вечеру: „ориза или каква друга сочива, црвене блитве која се зове кумбус, бијелог главатог купуса или раштана под со и уље” (Врчевић 1883: 22), божићне хлебове, а домаћин припрема сада већ суву пастрву - у казан: „сасијече двије полутице брављег меса, двије бедрице и два плећа, двије три оке сланине и полу потрбушине прашјеће, ${ }^{3}$ а уз ово пе-шест ока говедине” (Врчевић 188: 320), ${ }^{4}$ све до обилне божићне трпезе - која се припрема месец дана унапред, као што се ваља. ${ }^{5}$ Интензивно се славе први дан Божића и наредна два дана (тзв. Божји дан - други дан празника и Св. Стефан, 9. јануара, трећи дан Божића), а славље се наставља понегде све до Св. Василија (14. 1), одн. Богојављења. Слична обредна пракса забележена је и у другим крајевима Црне Горе (уп. Павићевић 1933: 146; Накићеновић 1999: 137-143 и др.) и Србије (Беговић 1986: 107-123; Петровић 1948: 228-233 и др.). Саставни део ових етнолошких описа чини и ритуално преждеравање: „Na ovim se gozbama jede i pije bez mjere i ne smije se ni pomisliti na neku štednju, a to za sva tri dana Božića" (Павићевић 1933: 152), чак - до мучнине и повраћања јер „о Божићу се опити и побљувати није никакве срамоте" (Караџић 1857: 10).

Поред најбројнијег варијантног круга песама, где коледари најављују празник и доносе „добар глас”, антиципирајући родно лето и благослов здравља, весеља (као еманације животне силе) и плодне године (најчешће - у усевима, стоци и у породици), односно варијаната песама где Божић позлаћује врата, довратке и кућу (Караџић 1988: бр. 194; Караџић 1898: 197, 198; Милићевић 1894: 173 и др.), бројни су и записи песама које су непосредније везане за слављење Божића и које актуелизују неке елементе ритуалне нор-

\footnotetext{
${ }^{3}$ Интересантно је како се овај опис подудара са стиховима песме коју Врчевић бележи. Поред елемената ритуалне норме, везане за симболику биља (дрвећа), појављују се одређена храна и пиће: „Наврћите добре овне на ражњевима, / Сијеците суво месо не мјерите га, / Налагајте сува дрва и ћепанице, / Приправ'те ми доста вина рујна црвена, / И ракије лозоваче прве бокаре" (Врчевић 1883: 25).

${ }^{4}$ Слично томе, после Бадње вечере спрема се мрс у Катунској нахији, а по њему се и гата: „Uveče se navjesi pinjata napunjena kastratine i pršute; ali mora biti i crne kobasice (napunjene svinjskim mesom). Kad se je navesila pinjata i počela da vri, potrlja se onaj spoljni gar po njoj, pa ako se pojavi po njoj puno onih sitnih iskrica, tj. ako gori onaj gar na pinjati, biće i para te godine" (Павићевић 1933: 150).

5 ,Već početkom decembra počinju pripreme, da se dočeka što svečanije Božić. Zaklata je svinja, a sa njom bar dva 'sitna brova' (koza ili ovca), i stavljene da se suše, 'da se imadu sa čim omrsiti na taj dan' i da im ko koga njihova ne mogne prekoriti: 'Ti se ni na Božić ne omrse.' Isto tako vodi se velika briga i da se imade pića, a naročito vina” (Павићевић 1933: 146).
} 
ме, везане за његово празновање. У песмама, препознатљивим по уводној формули Божић зове, тј. Божић иште, каталози хране уобличени су као списак обавезних намирница, које Божић захтева: вино, ракију, месо, ђевеницу (Караџић 1866: бр. 352), уз пропратне радње, значајне за прослављање празника (Караџић 1898: бр. 188).

На различите начине исказан (као императив младог бога, питање колеђана да ли је све припремљено за божићну трпезу, глас који најављује родну годину и сл.), у детаљима вариран, ритуални норматив богате трпезе садржи следеће намирнице: хлеб, вино, печенииу (најчешће прасе), ${ }^{6}$ понекад и сир, мед и ракију.

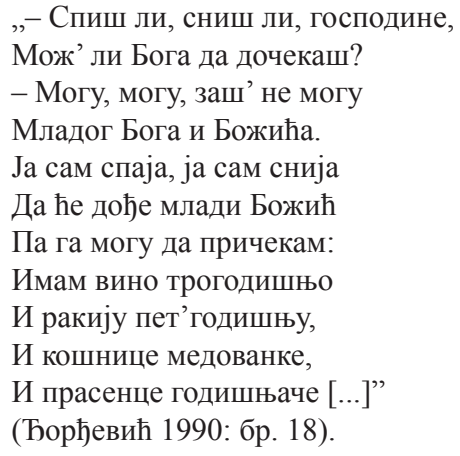

Најсведеније стилизован, овај попис обухвата само култне намирнице - хлеб и вино:

„Домаћине, господине, коледо! Застасмо те за трпезу, коледо! На трпезу златна чаша, коледо! Златна чаша и погача, коледо!" (Златановић 1982: бр. 4)

Трпеза је центар куће, а тиме и центар обредних дешавања. На њој доминантно место заузимају божићни колач, кружног облика и слојевите семантике, као и златна чаша, која симболиком круга и злата, везаним за сунце и светлост, кореспондира са свеукупном соларном симболиком овог празника у коме доминантно место има култ сунца (уп. Зечевић 2008: 81-85). Ови поетски и обредни реквизити доприносе свеукупној свечарској атмосфери - прослављања мистерије рађања Младог Бога, новог Сунца, које од зимске краткодневице почиње циклички да ојачава, те Божић постаје празник обновљене моћи вегетације, свеукупне аграрне и сточарске плодности, као и обновљене животне снаге заједнице, која резултира рађањем мушког потомства (в. Караџић 1898: бр. 207, 208 и др.).

${ }^{6}$ В. попис различитих обредних хлебова и божићне печенице, уз тумачење неких елемената њихове семантике и симболике у: Торњански Брашњовић 2015: 72-81. 
Слојевита симболика божићног обредног хлеба (божићњака, погаче, чеснице, краваја, колача и сл. - в. СМ 2001: 577) и вина „које у обредима симболизује крв, здравље и живот" (СМ 2001: 82), кодирана је традиционалном културом и датим моментом календарског циклуса, а потом преслојена хришћанском обредношћу (тело и крв Христова, света евхаристија). Уз то, божични колач и(ли) чесница кориштени су у магијске сврхе - по њеној површини се гатало, као и по томе шта ко од укућана нађе у свом парчету. По томе је предодређиван успех летине у наредној години, пре свега пшенице (СМ 2001: 578; Станојевић 1929: 52-53), а служе и за стимулисање плодности - у тору и на њиви (Караџић 1857: 11).

Сем поетске слике празничне трпезе, на којој доминантно место имају обредни хлеб и вино, приказан је и Божић који реже (обично три) кључне намирнице. Овим формулативним поступком (композиционим шаблоном) каталог хране сведен је на три култна (обично месна) јела - трочлани асиндетски низ. Варијантни круг песама са мотивом три ножића - један од типичних и најшире најраспрострањених (од Крајине и Босне до јужне Србије и Македоније). Ове песме чувају повезаност текста песме и обредног контекста извођења. Разлике у текстовима ових песама углавном се дају свести на другачије локалне обичаје, везане за божићну трпезу, а рефлектују се и у разликама у каталозима хране у песмама - често, и у оквиру исте регије. ${ }^{7}$

Тако, у песмама, „три ножића” режу печенииу, Ђевенииу ${ }^{8}$ (врста кобасице - Д. П.) и погачииу (у Херцеговини - в. Врчевић 1883: 24), али и гибаниuу, Ђевенииу, заоблииу ${ }^{9}$ (Херцеговина и Црна Гора - уп. Караџић 1898: бр. 194), чеснииу, печенииу, кобасииу (Милићевић ${ }^{2} 1984:$ 172; Грбић 1909: 96; Вукановић 1975: 128; Николић 1966: 7; Бован 2000: бр. 45), веселииу (печена на ражњу овца или свиња), печенииу, погачииу (Грђић Бјелокосић 1985: 96), печенииу, чеснииу, сираи (Милићевић ${ }^{2} 1984: 172$ ) и сл. Каталог намирница углавном је условљен обичајима око божићне трпезе и варира од места до места, чак од куће до куће. Ипак, примећује се да већина варијаната ове песме има као обавезне култне намирнице: погачу, печенииу и кобасииу.

Божићна печенииа (заоблица, веселица, масница, божићњак и др.), примарно је била култна жртва, да би, заборављањем изворне семантике, постала ритуална храна, која оличава жеље везане за приплод стоке за наредну годину. За њу се бирала култно чиста животиња: „бела и без икаквог телесног недостатка”, а „њено убијање обављало се на ритуалан начин. Обично се то чинило пре подне, док дан напредује. Избегавала се употреба секире.

7 „Najkarakterističnija lirska obredno-božićna pesma koja se recituje u svim selima [Livanjskog - prim. D. P.] Polja, kao i u samom Livnu, jeste 'do Božića tri nožića'. Tekst je istovetan kod svih Srba i Hrvata, a razlika je samo u nazivima za elemente obrednog kulta: Hrvati i Srbi ikavci režu 'česnicu' ('našarani kruv'); kod Srba ijekavaca to je 'prisni kruv' tj. hleb bez kvasca - pogača -, 'mesnicu' ('pečeno bravče'), 'sir i maslo'. Hrvati nekih sela (Lusnić, Guber) režu i 'sirnicu' ('veliki masni sir'), zatim 'slasnicu' (nešto slatko) i 'masnicu' ('pečeno bravče'). Srbi ijekavci za pečeno bravče imaju termin 'pečenica i veselica' i Hrvati iz Ljubunčića kažu 'pečenica'. Zatim Srbi ijekavci imaju i 'varenicu' - 'vriško meso"' (Симић 1961: 313).

${ }^{8}$ Ђевеница - врста кобасице (Д. П.).

9 Заоблица - свиња или овца, печена уцело на ражњу - Д. П. 
Коришћен је искључиво нож. Понегде су животињу убијали крупицом соли у чело" (Бандић 1991: 303). Крв печенице, као и делови тела користили су се за магијско стимулисање приноса усева, родности воћака и размножавање стоке, па и за лечење (Исто). Крај њеног печења оглашавао се пуцањем пушака (Врчевић 1883: 29; Грбић 1909: 88-89 и др.), у кућу се уносила главом напред (Грбић 1909: 89), а гледањем у плећку прорицао се напредак куће, будућност домаћина и судбина чланова породице. ${ }^{10}$

Учестало појављивање кобасице (Ђевенице) у овом варијантном кругу (11 од 15 посматраних примера) указује на то да она има значајно место на божићној трпези, као и у контексту божићне обредности. Античке паралеле потврђују древност, али и култну вредност овог ритуалног и (карневалског) специјалитета, ${ }^{11}$ као и везу са сточарским култовима, оличену у раскомаданом териоморфном божанству - тотемској животињи, покровитељу стоке.

Cup који се износи на божићну трпезу такође је култна храна јер је он „на Ивањдан усирен и у скорупу сачуван” (Беговић 1986: 118). Обједињујући у себи симболику слабог (младог) Сунца (зимска краткодневица) и јаког Сунца (летња дугодневица - Ивањдан), односно крајње тачке соларног циклуса, овај сир, сачувавши магијску снагу ,јаког” сунца за време летњих жега (Ивањдан - 7. јула), и реликте култа ватре, везане за мистерију сунчевог периодичног јачања и слабљења, прикључен божићној трпези, има за циљ да магијски поспеши јачање младог сунца, евоцирајући време његове пуне снаге.

Гибанища (Караџић 1898: бр. 194) представља култно јело које (уз божићни колач) повезује сточарске култове (сир) и аграрне (коре од пшеничног брашна), те укршта и амалгамише у слојевитој семантици божићних празника значењске нивое пореклом из различитих фаза развоја словенске митологије.

Малобројни сачувани примери указују на то да је, по свој прилици, семантика жртве и жртвовања некада била примарна у тематском кругу божићних песама с мотивом „три ножића”:

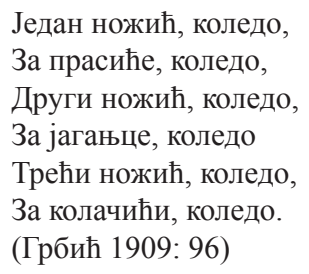

${ }^{10}$ Врснији „читачи” из плећке умели су, како се верује, да предвиде погибију или опасност, као и дужину и ток ратова (в. Казимировић 1999: 167-176).

11 Етимолошки, „'сатура' је 'надев', 'кобасица', 'пудинг', 'млевени надев"” (Фрејденберг 2011: 197). Иста реч на старогрчком, поред хране од плодова и семења и ,драмског жанра у метричкој форми” (Исто), означава „масно јело; колаче, кобасице, иситњене надеве - култна јела која садрже фил" (Исто: 198) који представља виши стадијум обликовања оног истог јела - рашчеречене, раскомадане животиње. Овоме треба додати да је такав уситњени надев, да је таква кобасица пуњена још и крвљу - и тада ће нам постати јасно да је метафора 'јела' овде једна иста, а да у тим кобасицама имамо стадијално, још позније обликовање, хомофагије” (Фрејденберг 2011: 199), тј. теофагије, у светлу дионизијских мистерија - све до семантике култног јела. 
Животиње у које се костимирају коледари, као и „огртање коледара кожухом, који се сматра олицетвореним претком” по мишљењу Зечевића, ,jедан је од остатака схватања да се душе предака могу реинкарнирати у животињама" (2008: 93). Коледари, на обредној равни, представљају остатак древних сточарских култова (Зечевић 2008: 113-114), што потврђује и бројност песама (ван основног корпуса грађе) у којима се магијски стимулише богат приплод стоке. Да је симболизам ритуалне жртве сачувао у нашој усменој традицији особеност преласка од териоморфизма ка антропоморфизму потврђује и пример забележен готово век касније. Иако настао као контаминација два сижеа „Божић бата” и разматраног (с централним мотивом „три ножића”), овај запис указује на својеврсну „поетику сећања”, захваљујући којој се, у сиже о храни, преко сижеа о жртвованој животињи, из понорних дубина колективног „памћења” враћа митски лик - антропоморфно биће (девојка):

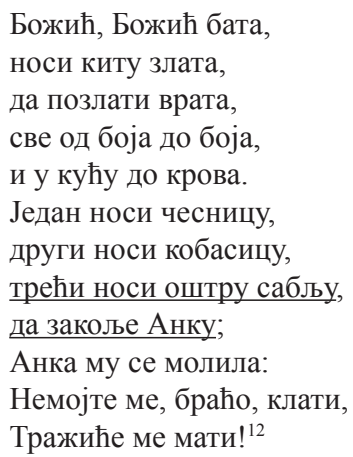

За разлику од других жанрова, у коледарским и божићним песмама сачуван је развојни пут у историјској поетици жанра и његова генетска веза с примарним ликом митског сижеа, који се у њему појављује - соларним/ сточарским/аграрним божанством, на шта је у овој реконструкцији указано. Обратним следом, тј. од система старијих представа ка млађим: „животињска претеча бога постаје атрибутивна животиња или пак жртвена животиња бога" (Фрејденберг 2011: 266). Преслојавањем старијих слојева млађим

[...] у земљорадничким култовима космичка оличења-тотеми претварају се у богове, као и резултат додавања нових метафоричких карактеристика на старе (које суштински остају непревазиђене), природа сваког бога је шаролика и мешовита, и функције једног се налазе међу функцијама другог. Ипак преовлађује плодност; богови персонификују домаћу стоку, живину, хлеб, зеленило, свеће, каше и чорбе, иначе једноставно полни орган ${ }^{13}$ (Фрејденберг 2011: 265).

${ }^{12}$ Овај мотив и присан однос мајке и кћери подсећају на мотив жртвовања тотемске животиње - краве, у коју је претворена мајка главне јунакиње из Вукове варијанте „Пепељуге”. Отворен крај песме (не зна се какав је одговор на девојчину молбу), као и оклевање приликом жртвовања (задршка док их девојка моли) могли би указивати на време када је људска жртва добила замену животињском (ритуална супституција).

${ }^{13}$ Обредни реквизит „мачуга” - штап који носи дед(иц)а (вођа коледарске поворке) има изразиту phallós-ну симболику (в. Зечевић 2008: 85-97). 
У том контексту, симболика жртвовања и жртве (материјализоване у виду обиља хране на божићној трпези) преплиће се с ритуалном праксом даривања као размене дара и уздарја: давањем дела обиља - превасходно хране $^{14}$ - обезбеђује се благослов коледара, који узвраћају жељом за напретком дома и домаћинства: „Симболика поклона указује на специфично уздарје, које је и својеврсна гаранција да ће жеље наћи пут до више силе и допринети родности и плодности новог циклуса" (Самарџија 2011: 568). Другим речима, „дарови у храни симболички представљају плодове чије се умножавање жели постићи магијским путем, односно песмом" (Торњански Брашњовић 2015: 204), при чему је на њихов жртвени карактер у контексту даривања коледара (душе предака или њихови ритуални аналогони) већ указивано (уп. Зечевић 2008: 72-105). Божићу се дарује жито (Караџић 1898: бр. 213), али и обредна храна, карактеристична за божићну трпезу, док уздарје може имати конкретни или апстрактни карактер:

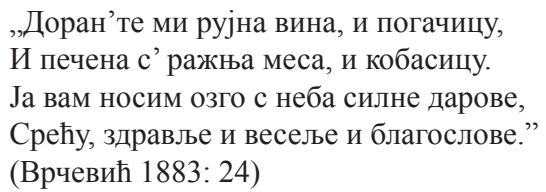

Притом, већина ових песама има отворену структуру, што је условљено њиховим обредним контекстом. Тако, једна од песама с мотивом три ножића упућује да се благодат богате трпезе дели са коледарима, гостима, сиротињи, као и унутар чланова породице:

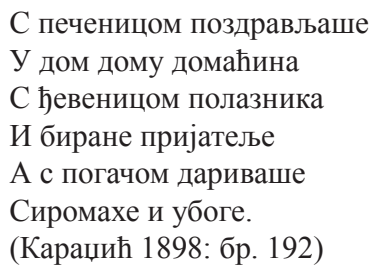

Затечено богатство, обиље приказани раскош и трпезе у дому приказани су хиперболично, без обзира на то да ли описује своје благостање домаћин (уп. Васиљевић 1960: бр. 1а, 2, 6, 13; 18, 19; Ђорђевић 1990: бр. 18, 19), полаженик (Јоцић и др. 1979: бр. 1) или коледари.

Њихов благослов подразумева одређено уздарје, или се коледарски дар експлицира у песми. ${ }^{15}$ Празнично претеривање у количини дарова које коледари траже (в. Караџић 1898: бр. 159; Васиљевић 1994: 4-5) контрастира сведеном уздарју - прецизно побројаним намирницама:

\footnotetext{
${ }^{14}$ „Најчешће се поклања храна (брашно, жито, јаја, ораси, сир, кајмак, сланина, месо, масло, вино, воће), вуна, платно, цвеће, дуван или рукотворине (рукавице, чарапе, пешкири), а за поједине празнике припремају се као дарови посебни колачи ('комка', 'буздован', 'кравајче', 'поливачки колач', 'сироварски кравај')" (Самарџија 2011: 568).

${ }^{15}$ В. Клеут 1983: бр. 8.
} 
„Дај, газда, колачић на штапић,

Чесницу на песницу,

Кобасицу у торбицу,

Дај, газда, вина,

Да наздравим свима."

(Карановић 1996: бр. 50).

Свечана прослава празника, уз изобиље хране и пића, као да дозива еротско и хуморно као другу страну празника, тј. своје карневалско наличје. Уз призивање божјег благослова, после ритуалног даривања, чароице изводе одређене ласцивне радње којима је циљ да обезбеде плодност (које се преносе у „текст”, указујући на нераскидивост везе „текста” и контекста):

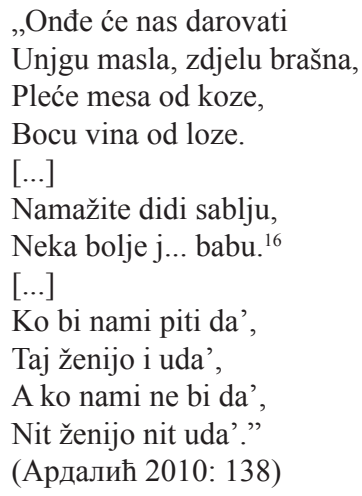

Елементи хумора преливају се тако из песме на ритуалну ситуацију, која завршава карневалским гестом ударања по туру, тј. снижавања светог госта (божанског представника) и његовог терања из куће (Ђорђевић 1990: бр. 16). ${ }^{17}$ Необични спрег смеха, мрсне трпезе и сексуалних асоцијација има исте изворе - у карневалско-празничном рушењу социјалних норми, при чему „dopuštanje smeha bilo je vezano s istovremenom dozvolom mesojeđa i polnog života (što je u vreme posta bilo zabranjeno)” (Бахтин 1978: 93). Отуда, „са сценама свадбе и сексуалног акта у обредима извођеним око Божића, комбинују се сцене смрти, комадања, дерања коже и васкрсавања стария [...] а све то заједно асоцира на првобитно комадање божанства од ког је настао свет, као и на аналогно ритуално комадање животиња" (Карановић, Јокић 2011: 172).

Млади Бог (Божић), тако, од слављеног божанства Сунца, плодности и обиља у контексту народне смеховне културе постаје карневалски ждероња - халапљивац (тематски круг песама с иницијалном формулом Божић зове/ иште). Симболика обнављања и рађања постаје нераскидиво повезана са сликама једења: „Trijumf gozbe je univerzalni trijumf - to je trijumf života nad

\footnotetext{
${ }^{16}$ Симулацију коитуса деде и бабе Карановић и Јокић виде као ритуално репрезентовање „еротског додира с Великом богињом мајком, с циљем да се магијским путем утиче на обнову природе" (2011: 167).

${ }^{17}$ Сличан тип празнично-карневалске смеховности присутан је у коледарским песмама које се певају на Бадњи дан, када деца полазе у колеђане - уп. Јастребов 1886: 30-31.
} 
smrću. U tom pogledu on je ekvivalentan začinjanju i rađanju. Telo koje je pobedilo prima u sebe pobeđeni svet i obnavlja se" (Бахтин 1978: 300):

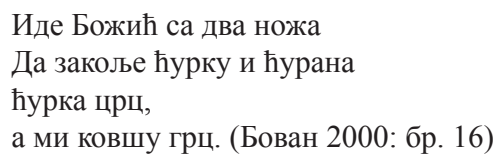

Митски лик даваоца обиља у карневалском контекту снижава се до обредне фигуре (јестиве лутке) и пијанца лакрдијаша („Иде Божић планином, / Загрн'о се сланином, / Од кулена пуце му, кобасице петље му / Пуно носи здравља / И складно весеље / Још чутуру вина / Да наздрави свима" - Караџић 1898: бр. 212), неодољиво подсећајући на Диониса - божанство плодности и вина, које периодично умире и васкрсава, не губећи, притом, своје атрибуте и функције припадајућег му аграрног симболизма. Мистерија смрти и васкрснућа божанства стоке и плодности прослављана је током дионизијских свечаности, односно Сатурналија, а мимички плес изводио је животињски хор, тј. учесници одевени у јареће коже (в. Фрејденберг 2011: 194). На словенском простору његов фолклорни аналогон јавља се у лику Божића, младога бога који својим рођењем најављује нови вегетативни циклус, док датум његовог обележавања (Божић) постаје празник једења (Фрејденберг 2011: 62). На равни обредне метафорике са семантиком хране, репрезентован је божићним колачем - „хлебом, који се истовремено сматра младом животињом, али и очовеченим божанством" (Фрејденберг 2011: 63) и божићном печеницом (симболом обнове и васкрсења - Фрејденберг 2011: 69), чију је аломорфност и изофункционалност - од бога који се рађа, умире и васкрсава, преко тотемске животиње, заштитника стоке који бива поједен/рашчеречен/ раскомадан, до жртвоване животиње (култне хране) - ова реконструкција показала на примерима одабраних фолклорних текстова (коледарских и божићних песама с мотивом хране).

\section{ЛИТЕРАТУРА}

Ардалић 2010: V. Ardalić, Bukovica: narodni život i običaji, Novi Sad: Srpsko kulturno društvo „Prosvjeta”.

Бахтин 1978: M. Bahtin, Stvaralaštvo Fransoa Rablea i narodna kultura srednjega veka i renesanse, Beograd: Nolit.

Беговић 1986: Н. Беговић, Живот Срба граничара, Београд: Просвета.

Бован 2000: Обредне народне песме: студентски записи српских народних умотворина на Косову и Метохији, В. Бован (прир.), Приштина: Институт за српску културу, Бања Лука: Бесједа, Исток: Дом културе „Свети Сава”.

Васиљевић 1960: М. А. Васиљевић, Народне мелодије лесковачког краја, Београд: Српска академија наука, Музиколошки институт, Научно дело. 
Васиљевић 1994: Избор обредних песама из необјављених записа Миодрага А. Васиљевића: из Србије, 3. М. Васиљевић (прир.), Београд: Расковник, XX/75-76, Београд, 3-12.

Врчевић 1883: В. Врчевић, Три главне народне свечаности: Божић, крсно име и свадба, Панчево: Наклада књижаре браће Јовановића.

Грбић 1909: С. Грбић, Српски народни обичаји из Среза бољевачког, Београд: Српска краљевска академија.

Вукановић 1975: Т. Вукановић, Српске народне лирске песме, Врање: Раднички универзитет.

Ђорђевић 1990: Д. Ђорђевић, Народне песме из лесковачке области, Београд: Српски етнографски зборник XCV, Београд: САНУ.

Ђурић 1934: С. Ђурић, Српски народни обичаји у Горњој Крајини, Београд: Српски етнографски зборник, L/1, Београд, 192-206.

Златановић 1982: М. Златановић, Лирске народне песме из јужне и источне Србије, Београд: Народна књига.

Јастребов 1886: И. С. Ястребов, Обычаи и $п$ Ђсни турецкихъ Сербовъ: въ Призрьнъ, Ипекъ, Моравъ и Дибрњ, С. Петербургъ.

Јоцић и др. 1979: Ж. Јоцић и др., Бул девојче: лирске народне песме из белопаланачког краја, Ниш: ИРО Градина.

Казимировић 1999: Р. Казимировић, Гатање и врачање, Београд: Силмир.

Карановић 1996: 3. Карановић, Антологија српске лирске усмене поезије, Нови Сад: Светови.

Карановић, Јокић 2009: 3. Карановић, Ј. Јокић, Смеховно и еротско у српској народној култури и поезији, Нови Сад: Филозофски факултет.

Карановић, Јокић 2011: 3. Карановић, Ј. Јокић, Обредни смех у песмама зимског календарског циклуса, Годишњак Филозофског факултета у Новом Саду, XXXVI/1, Нови Сад, 163-177.

Караџић 1857: В. С. Караџић, Живот и обичаји народа српскога, Београд: Српска књижевна задруга.

Караџић 1866: Српске народне пјесме из Хериеговине (женске), за штампу их приредио Вук Стеф. Караџић, у наклади Ане удове В. С. Караџића, Беч.

Караџић 1898: Српске народне пјесме: књига пета у којој су различне женске пјесме, скупио их В. С. Караџић, Београд: Државно издање.

Караџић 1988: Српске народне пјесме: књига прва у којој су различне женске пјесме, скупио их и на свијет издао В. С. Караџић, В. Недић. (прир.), Сабрана дела Вука Караџића, књ. 4, Београд: Просвета.

Клеут 1983: М. Клеут, Лирске народне песме у Летопису матице српске, Нови Сад: Матица српска.

Младеновић, Недић 1973: Српске народне пјесме из необјављених рукописа Вука Стеф. Караиића: књ. 1, различне женске пјесме, Ж. Младеновић и В. Недић (прир.), Београд: САНУ.

Милићевић 21894: М. Ђ. Милићевић, Живот Срба сељака, Српски етнографски зборник, I, Српска академија наука, Београд.

Накићеновић 1999: С. Накићеновић, Бока, Подгорица: ЦИД. 
Николић 1966: Горо ле, горо зелена: антологија народне лирике из источне Србије, И. Николић (прир.), Зајечар: Новинска установа „Тимок”.

Павићевић 1933: M. Pavićević, Običaji (Katunska Nahija u Crnoj Gori), Zagreb: Zbornik za narodni život i običaje južnih Slavena, XXIX/I, Zagreb, 146-180.

Петровић 1948: П. Петровић, Живот и обичаји народни у Гружи, Београд: Српски етнографски зборник, LVIII/26, Београд.

Самарџија 2011: С. Самарџија, Од жртве до пешкеша: функција дара и даривања у усменој књижевности, у: М. Детелић, С. Самарџија (ур.), Жива реч, Београд: Балканолошки институт САНУ, Филолошки факултет, 561-589.

Симић 1961: Lj. Simić, Narodne pesme, Sarajevo: Glasnik Zemaljskog muzeja u Sarajevu: etnologija, XV-XVI/1960-1961, Sarajevo, 289-322.

СМ 2001: Словенска митологија, С. М. Толстој и Љ. Раденковић (ред.), Београд: Zepter Book World.

Станојевић 1929: М. Станојевић, Обичаји и веровања на Тимоку, Београд: Гласник етнографског музеја, IV, Београд, 42-54.

Торњански Брашњовић 2015: С. Торњански Брашњовић, Коледарске и божићне песме у контексту зимских календарских обреда, Нови Сад: Филозофски факултет (рукопис докторске дисертације).

Фрејденберг 2011: О. М. Фрејденберг, Поетика сижеа и жанра, Сремски Карловци, Нови Сад: Издавачка књижарница Зорана Стојановића.

Dragoljub Ž. Perić

\title{
REPRESENTATION OF FOOD AND DEPICTIONS OF FEASTS IN SERBIAN ORAL KOLEDA AND CHRISTMAS CAROLS
}

\author{
(Summary)
}

In this paper, food motifs and catalogs of meals are observed in 100 Serbian Christmas carols, selected on the basis of their representativeness or archaicity by using a structural-semiotic methodology. Unlike previous research, mainly folkloristic in character, this paper primarily builds on a poetic foudation, although the ritual context is not ignored. The main aim is to show, by means of notions, related to cult food (primarily Christmas roasts and bread), how this corpus of carols reflects a gradual transition from human to animal sacrifice, i.e. how tradition retains the older (teriomorphism) and younger (anthropomorphism) types of beliefs at the same time. 